\title{
How Relevant Are Non-Use Values and Perceptions in Economic Valuations? The Case of Hydropower Plants
}

\author{
Sara Sousa ${ }^{1(D)}$, Anabela Botelho ${ }^{2}$, Lígia M. Costa Pinto ${ }^{3, *}$ and Marieta Valente ${ }^{3(D)}$ \\ 1 Coimbra Business School/ISCAC and CERNAS, Polytechnic Institute of Coimbra, \\ 3040-316 Coimbra, Portugal \\ 2 DEGEIT and GOVCOPP, University of Aveiro, 3810-193 Aveiro, Portugal \\ 3 EEG and NIPE, University of Minho, 4710-057 Braga, Portugal \\ * Correspondence: pintol@eeg.uminho.pt; Tel.: +351-253-604-586
}

Received: 14 July 2019; Accepted: 1 August 2019; Published: 2 August 2019 updates

\begin{abstract}
The construction of hydropower plants, particularly of large ones, is far from being a consensual decision: advocates defend their construction based on the unquestionable benefits hydropower provides, while critics argue that these facilities are far from harmless and cause adverse impacts on the environment, being not only against the construction but also demanding the destruction of existing ones. We review a selection of recent empirical studies concerning impacts of hydropower developments, to make a case for the consideration of non-use values in the economic valuation of the environmental and social impacts of hydropower plants, through the use of non-market valuation methodologies. Additionally, we present data from a case study of hydropower economic valuation, where different subgroups of the population with differing degrees of contact and familiarity with hydropower rate their perception of impacts. Respondents with more contact are less penalizing of hydropower than other respondents. We conclude that non-use values are non-negligible and can be valued through stated preference methods, but researchers should take into consideration perceptions and the role of users and non-users. Non-use values should thus not be neglected by policy makers and regulators at the planning and public consultation stages or as part of the decommissioning decision.
\end{abstract}

Keywords: total economic value; hydropower plants; economic valuation; public perceptions

\section{Introduction}

Appraising the social desirability of an energy generation project is a complex task. From an economic perspective, a project is considered efficient if the sum of its benefits outweighs its costs in financial, economic, social and environmental terms, in which case social welfare increases relative to the initial situation. Focusing only on benefits and costs with a monetary value in the market neglects what can potentially be a significant component of social value. In particular, in the case of environmental impacts of energy projects, there are benefits and costs that may impact the net worth of a project but are not directly valued in the market. When it comes to renewable energies sources (RES), there are not only environmental benefits, in particular the reduction of greenhouse gas (GHG) emissions, but also non-negligible negative impacts, which need to be considered [1-3]. The same happens with the psychological and social issues: if, on the one hand, hydropower, as a renewable source, benefits from wide acceptance by the general population, the same is not true among local residents whose well-being is clearly affected by the day-to-day operation of hydropower plants in the vicinity of their residences [4-6]. To account for economic values of these adverse impacts, economists have included in their toolkit 
non-market valuation methods which allow researchers and policy makers to value the externalities of projects, in particular to provide a monetary approximation to the so-called non-use values. By monetizing different components of the total economic value (TEV) associated with environmental and social impacts of a project, it is possible to compare it like-for-like with financial and economic net returns.

In this paper, we focus on the case of hydropower plants, whose construction decision is difficult and far from being consensual, given the many implications for development, the environmental and social justice [7]. On the one hand, many agents defend the construction of hydropower plants based on the unquestionable benefits they provide for energy and water supply, flood management, irrigation possibilities, promotion of tourism and the many associated employment opportunities (e.g., $[8,9]$ ). There are others who consider that these facilities are far from being harmless and that the advantages clearly do not compensate the many adverse impacts on the environment $[4,10-12]$. In addition to affecting the environment, the day-to-day operation of hydropower plants can be extremely uncomfortable for local populations, generating a clear decrease in the well-being of these populations. Richter [13] highlights that communities living downstream from damned river have been affected in their river-dependent livelihoods associated with fish and agricultural activities, but have often been ignored when appraising dams' impacts. Additionally, hydropower projects have often implied the displacement of local communities and their resettlement elsewhere, sometimes involuntary [14-17].

These environmental and social adverse impacts associated with hydropower justify the increasing lack of social acceptance particularly felt among local communities, and an increasing number of studies making the case for the option of dam removal as an answer for many critical social and environmental problems (e.g., [18-23]). Furthermore, nowadays it is estimated that in Europe and the US more hydropower plants are being decommissioned than built [24], so it is likely that the environmental and social consequences of dam removal will become increasingly pertinent, and even the science around this issue will need further developments $[25,26]$.

The controversies around hydropower are amplified when it comes to large dam projects. Noteworthy impacts of large projects involve large population displacements, and have in the past included human rights abuses during the pre-construction phases [27]. The accelerated construction of large dams in previous years, gave rise to a global debate under the World Commission on Dams [28] in the late 2000s, but that is still pertinent a decade later [29] and today [30]. One of the main recommendations from the commission as summarized by its secretary-general was that "decisions about whether a dam should be built and how it should be operated, or whether better alternatives exist, must reflect the multiple impacts and risks and benefits that such projects imply for different stakeholders." ([29], p. 2).

As we can infer, hydropower plants' adverse impacts have been well identified in the literature for more than two decades; however, cost-benefit analysis on hydropower developments continue to neglect these impacts since the losses and reductions in amenities are mostly non-market goods or services, and therefore are not captured by market prices. Additionally, many of these losses are valuable for society in terms of non-use values but their consideration in monetary terms is not straightforward.

Mattmann et al. [1] note in a recent meta-analysis of hydropower externalities that much more attention has been devoted to the economic valuation of externalities associated with other renewables other than hydropower. However, as the importance of RES for electricity production continues to increase (the International Energy Agency estimates that in 2017 renewables account for one quarter of electricity generation, which is expected to rise to $41 \%$ by 2040 ), hydropower is, and is expected to continue to be, the most important RES [31]. It is therefore important to understand how to account for all components of the TEV of environment impacted by hydropower projects, both old and new.

In a context of continuing importance of hydropower for electricity generation, we propose to guide the reader through the economic concepts of TEV and stated preference methods as applied to dams and hydropower, so as to present an overview of recent studies on the economic valuation of non-use values. While other renewables have attracted more attention from researchers using this 
economic toolkit, the few studies conducted and surveyed in this paper that have applied non-market valuation methods have opted to value non-use values using stated preference methods. These studies on the one hand highlight the non-negligible importance of non-use values, giving strength to the argument that these should be fully acknowledged. On the other hand, these studies mostly focus on the operation of existing dams, rather than on ex-ante analyses or removal cases, thus identifying a gap in the literature, all the more relevant given both the decommissioning of older infrastructures and commissioning of new hydropower plants in developing countries [24].

Furthermore, the value attributed to impacts of hydropower, in particular non-use components (impacts on nature, landscape interference, heritage destruction, etc.), is likely to differ according to different subgroups of the population. On the one hand, local residents will not only value some of those components for their existence value but also for their use value, while other people will mostly value them as non-users. On the other hand, the acquaintance and familiarity with hydropower will change how individuals perceive those impacts in terms of severity and nuisance, which will in turn impact value estimates. In this paper, we present evidence to illustrate the importance of considering different population subgroups in terms of perception of impacts. While we would expect individuals closer to hydropower plants to perceive their impacts more severely, we observe that, on the contrary, it is those with less contact, whom we deem to be non-users, who are more critical. We believe this is a result that warrants future research. This is a relevant result for future studies, that should adequately control for the relation of respondents to hydropower projects in the elicitation of use and non-use values.

The remainder of this paper is organized as follows. Section 2 provides an overview of the key concept of TEV and discusses different components of TEV affected by the activity of hydropower plants based on a review of empirical studies since the year 2000 that have used economic non-market valuation methods to study hydropower. This section aims to be a quick and up-to-date reference for policy makers and practitioners on the main concepts in the economist's toolkit that can be applied to appraise new and existing hydropower projects without neglecting non-use values. In Section 3, we present the case study and the results that illustrate how different population subgroups perceive hydropower impacts. This section extends the existing literature by highlighting that care should be taken when approaching different population groups to elicit non-use values. Finally, the main conclusions are presented along with policy and research implications.

\section{Hydropower Adverse Impacts Through the Lens of Economic Valuation Methods}

\subsection{Introduction}

Despite the well-known benefits for water and energy supply, flood management and irrigation, hydropower plants can also have negative impacts on the environment, including imposing biodiversity loss and adverse effects on the surrounding fauna and flora, requiring the flooding of cultivable land, contributing to the degradation of water quality, generating noise, intruding on landscape, and requiring the destruction or displacement of sites of architectural or historical importance [1]. Moreover, the activity of dams, particularly large dams, may cause psychological and social problems, especially for those living in the local communities near the facilities. Most of these damages are not directly included in the appraisal of hydropower developments mainly because their economic value is difficult to estimate, since there are no markets for the goods and services impacted and, therefore, prices are not available, which does not necessarily mean they have no value.

Based on a selective literature review for empirical studies, we present in Table 1 a collection of 29 studies (from 2000 to 2018) on economic valuation of the environmental and social impacts caused by the operation of hydropower facilities. These purport to infer, through the application of different non-market economic valuation methods, different environmental and social values directly or indirectly affected by the activity of dams. Using these studies as a reference, we will next present the concept of TEV as related to hydropower projects and how non-market valuation methods allow researchers to approximate those values, so that they are not neglected in the appraisal of projects. 
Table 1. Economic Valuation of the Dams' Impacts.

\begin{tabular}{|c|c|c|c|c|c|}
\hline & & Values & Study & Country & Attributes Affected \\
\hline \multirow{9}{*}{ 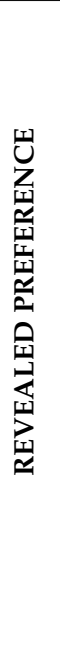 } & \multirow{6}{*}{ 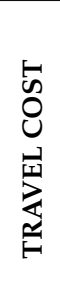 } & \multirow{9}{*}{ 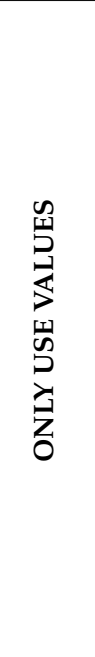 } & Loomis (2002) [32] & USA & River recreation \\
\hline & & & McKean et al. (2005) [33] & USA & River recreation \\
\hline & & & Hynes \& Hanley (2006) [34] & Ireland & Whitewater kayaking \\
\hline & & & Robbins \& Lewis (2008) [35] & USA & Recreational fishing \\
\hline & & & Getzner (2014) [36] & Austria & River recreation \\
\hline & & & Borisova et al. (2017) [37] & USA & Recreational activities \\
\hline & \multirow{3}{*}{ 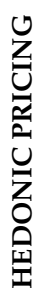 } & & Lewis et al. (2008) [38] & USA & $\begin{array}{l}\text { Aquatic ecosystems, fauna, flora, recreation } \\
\text { activities, attractiveness of houses near the } \\
\text { river }\end{array}$ \\
\hline & & & Provencher et al. (2008) [39] & USA & Property values affected from dam removal \\
\hline & & & Bohlen \& Lewis (2009) [40] & USA & $\begin{array}{l}\text { Rivers, fish, wildlife, local communities, } \\
\text { residential properties values }\end{array}$ \\
\hline \multirow{20}{*}{ 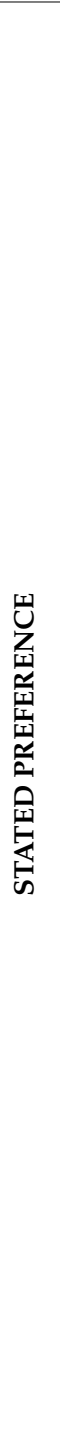 } & \multirow{9}{*}{ 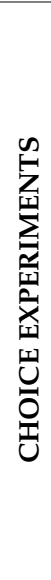 } & \multirow{20}{*}{ 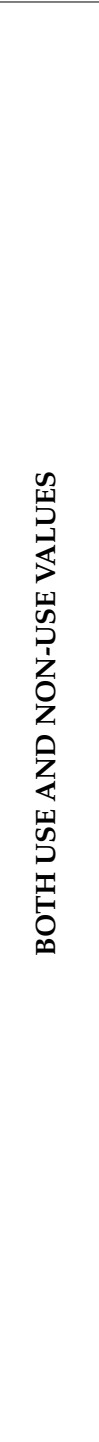 } & Sundqvist (2002) [41] & Sweden & Water level, vegetation and fish \\
\hline & & & Bergmann et al. (2006) [42] & Scotland & $\begin{array}{l}\text { Landscape, wildlife, air pollution and } \\
\text { employment }\end{array}$ \\
\hline & & & Han et al. (2008) [43] & Korea & Fauna, flora, forest and historical remains \\
\hline & & & Kataria (2009) [44] & Sweden & $\begin{array}{l}\text { Fish, birds, benthic invertebrates and } \\
\text { vegetation }\end{array}$ \\
\hline & & & Vega \& Alpízar (2011) [45] & $\begin{array}{l}\text { Costa } \\
\text { Rica }\end{array}$ & River water flow and scenic view \\
\hline & & & Klinglmair et al. (2015) [46] & Austria & Nature and landscape \\
\hline & & & Xu et al. (2015) [47] & China & Drinking water sources \\
\hline & & & Botelho et al. (2015) [48] & Portugal & $\begin{array}{l}\text { Fauna and flora, heritage, noise and } \\
\text { landscape }\end{array}$ \\
\hline & & & Tabi, \& Wüstenhagen (2017) [5] & Switzerland & Social acceptance \\
\hline & \multirow{11}{*}{ 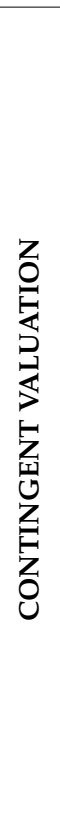 } & & Michailidis (2006) [49] & Greece & $\begin{array}{l}\text { Agriculture, irrigation, tourism, water } \\
\text { quality, recreation, health, social and } \\
\text { environment }\end{array}$ \\
\hline & & & Hakansson (2009) [50] & Sweden & Wild salmon \\
\hline & & & Ehrlich \& Reimann (2010) [51] & Estonia & Natural river water flow \\
\hline & & & Alp \& Yetis (2010) [52] & Turkey & Land \\
\hline & & & Gunawardena (2010) [53] & Sri Lanka & $\begin{array}{l}\text { Historical monuments, landscape, } \\
\text { recreational activities, river scenic view, } \\
\text { carbon storage, forests and home garden } \\
\text { productivity }\end{array}$ \\
\hline & & & Ponce et al. (2011) [54] & Chile & Landscape \\
\hline & & & Aravena et al. (2012) [55] & Chile & $\begin{array}{l}\text { Landscape, fauna, flora, river sports, } \\
\text { agriculture, tourism, fishing and displaced } \\
\text { inhabitants }\end{array}$ \\
\hline & & & Jones et al. (2016) [6] & USA & Social issues \\
\hline & & & Botelho et al. (2016) [56] & Portugal & Social sustainability \\
\hline & & & Jones et al. (2017) [57] & USA & GHG emissions reduction \\
\hline & & & Jones et al. (2018) [58] & USA & $\begin{array}{l}\text { Fauna and flora, pollution, GHG emissions, } \\
\text { recreation, rural life, among others }\end{array}$ \\
\hline
\end{tabular}




\subsection{The Concept of Total Economic Value (TEV)}

The concept of TEV is used as a framework that allows researchers to measure the economic value of non-market assets, as is the case of environmental goods and services. It represents a reference framework to assess changes in individuals' well-being from environmental impacts associated with a new policy or project [59]. The concept of TEV was developed to ensure that the value of the natural environment included more than simply the marketable raw materials and physical products. Neglecting other components of the value of the environment would lead to systematically underestimating the value of environmental goods and services, and in turn to decisions that would be suboptimal from an economic perspective, this generating losses for society [60]).

There are several approaches to the definition of TEV. Bateman et al. ([61], p. 28) state that "the net sum of all relevant willingness-to-pay (WTP) and willingness-to-accept (WTA) defines the TEV of any change in wellbeing due to a policy or project". According to Torras ([62], p. 286) it is "the sum of its direct, indirect, option, and existence values". Other studies consider the sum of the non-marketable and marketable values ([62], p. 283). Although distinct, these definitions are complimentary in that all contribute to better understanding this encompassing concept.

The TEV of an environmental good or service is associated with its attributes, which can either relate to the use or non-use values of the good or service. According to some authors (e.g., $[59,61])$, use values mean there is an actual use of the good or service, or that the use is planned or possible. As for actual use, it can be direct or indirect.

The actual direct use value can be first of all extractive, which implies that the quantity left for others is reduced (e.g., the extraction of water for irrigation); secondly, it can be non-extractive when the quantity if nor reduced for others (e.g., enjoying recreational amenities such as water sports or bird watching) [63,64]. In the case of recreational activities afforded by rivers, there is a decrease in this direct use value when a particular area is dammed-up [36]). On the contrary, the construction of a new hydropower project may create new recreational activities associated with the reservoir and thus generate a benefit rather than a cost.

The actual indirect use value is experienced indirectly by individuals or as a consequence of the primary function of a given resource. This is the case of regulating services provided by the ecosystem which contribute indirectly to the enjoyment of other final consumption amenities (e.g., forests' ability to sequester $\mathrm{CO}_{2}$ and produce $\mathrm{O}_{2}$ creates positive climate externalities and reduce health risks; hydropower as an alternative to fossil fuels contributes to reduce greenhouse gas emissions) (e.g., [57,62-65]).

The planned use component refers to use in a specific future date (e.g., a planned recreational trip to a natural area) $[59,61]$.

Actual and planned uses are straightforward concepts, which is not the case with possible use, also known as option value. This notion was first introduced by Weisbrod [66] to define the price of conservation, namely the willingness-to-pay for preserving a good or service with only the option of a future use. As stressed by Alcamo et al. ([63], p.133), "despite individuals not currently be deriving any utility from the environmental goods or services, they still have the option to use them in the future". This is not a consensual concept, with different interpretations in the literature: only uncertain benefits may be considered (e.g., [62]) or benefits already known but whose use was delayed (because of irreversibility for instance) or alternatively both types can be considered (e.g., [59,61]. In some studies (e.g., $[63,64]$ ) both certain and uncertain future benefits are considered in the TEV, respectively option value and quasi-option value. Finally, it is important to underline that sometimes option value and quasi-option value are not considered as use value, but rather as a component of non-use value.

Non-use values or passive use values correspond to cultural, moral, religious or aesthetic attributes as perceived by the individual who is making the assessment [67]. For instance, Freeman [68] considers that non-use value is the component that is not captured by revealed preference techniques. For Kolstad [69], non-use values result from the satisfaction of knowing that ecosystem services are conserved and that others can access to them in the present or in the future. Others argue that non-use value refers to the willingness-to-pay to preserve the existence of a good or service even in the absence 
of actual, planned or possible use [59,61]. We follow this latter approach, according to which non-use value can be classified in terms of (a) existence value, (b) altruistic value, and (c) bequest value.

Existence value was first defined by Krutilla [70] as the satisfaction that an individual gets from knowing that good or service will be preserved, and is independent of personal present or future use. Motivations vary and may include the concern for the asset itself (e.g., a threatened species) or a feeling of responsibility for the asset. Some authors (e.g., [71,72]) do not make a distinction between the closely related concepts of existence value and intrinsic value: existence value depends on individual preferences whereas intrinsic value is independent of human needs and tastes. For Madariaga et al. [73], existence value is associated with non-use value, and even a type of use value like "vicarious consumption" (e.g., viewing TV programs about tropical wildlife). At the other extreme, Bergstrom and Reiling [74] limit existence value to cognitive value, that is the value that comes from being able to "think about" the asset.

Altruistic value is related to intra-generational equity concerns, and the individual derives value from the fact others in the present can benefit from the good or service. Similarly, bequest value extends the concern to inter-generational equity and considers the next and future generations $[61,64,75]$.

As argued by Crowards [76], non-use values do not depend on the expected or present use or contact with the good or service, but merely on the knowledge that it exists, either for its own sake, to benefit others or to benefit future generations. As such, concerns about the irreversibility associated with the use of the resource are accounted for in the concept of TEV. Similarly, intra- and inter-generational equity concerns are considered, albeit from the perspective of present individuals who are making the assessment.

To summarize, Figure 1 presents TEV by types of value according to the approaches put forward by several authors.

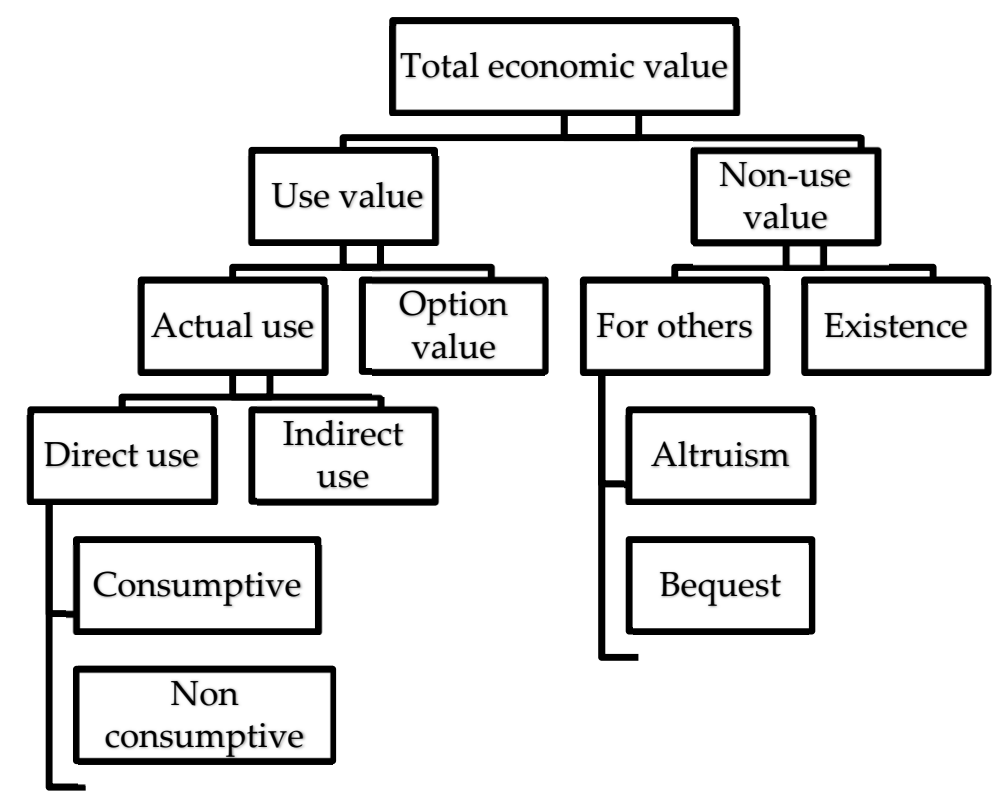

Figure 1. Total Economic Value. Adapted from Bateman ([61] p. 29), Pearce ([75] p. 87) and TEEB ([64] p. 14).

Non-use values are thus relevant in the analysis of the costs and benefits of a project with impacts on environmental and cultural assets. Their consideration and estimation is however not always straightforward and depends on the specificities of the case study and who is being asked to value a particular good or service. When hydropower impacts for example a natural landscape, as in the case of a waterfall region in Estonia, the aesthetic and touristic value would be significantly decreased by a proposed reduction in the water flow. Ehrlich [51] conducts a study to estimate how much national residents would pay to preserve the water flow. For Estonians who are likely to visit the region, the elicited values are use vales, whereas for other Estonians they would constitute non-use values. 
In a case study in Sweden, Hakansson [50] studies the benefit for society of improving the wild salmon population negatively impacted by hydropower. A survey of the general population using a non-market valuation technique reached both anglers and non-anglers, whose perceptions of the benefit from this improvement in the salmon population may differ. For anglers, elicited values are more likely to be mostly use values, albeit potential, whereas for non-anglers, elicited values are likely to be solely non-use values.

Additionally, the perception of impacts of hydropower among different population groups are likely to differ, as in the population of anglers and non-anglers or in the case we present in this paper, among residents near projects and non-residents. We present evidence from a case study to support this hypothesis.

\subsection{An Overview of Non-Market Valuation Methods}

Non-market valuation methodologies aim to estimate the value of environmental goods and services by considering individual preferences through the common metric of money $[68,77,78]$. The different methodologies have traditionally been classified as indirect methods (the so-called revealed preference methods) or direct methods (the so-called stated preference methods).

A revealed preference method gathers information about individual preferences for marketable goods that are related to the non-market good under valuation, either as complements or substitutes. These methods can only measure the use value of the goods or services. Specifically, there is the travel cost methods, the hedonic price method, and the averting behaviour technique.

Stated preference methods directly elicit individual preferences for a change in the level of provision or quality of an environmental resource, normally through questionnaires. The elicitation of individual valuations is developed within a hypothetical market scenario for the environmental good or service. These methods allow researchers to measure both the use and the non-use values of goods. There are two main approaches: the choice modelling and the contingent valuation approaches. The former includes choice experiments, contingent ranking, contingent rating and paired comparisons. In addition to eliciting total value from users and nonusers and being suitable for ex-ante and ex-post application, we stress that by incorporating non-use values into valuation procedures, the stated preference methodologies can more accurately reflect the full worth that society attributes to an environmental asset. These techniques are diagrammatically presented in Figure 2.

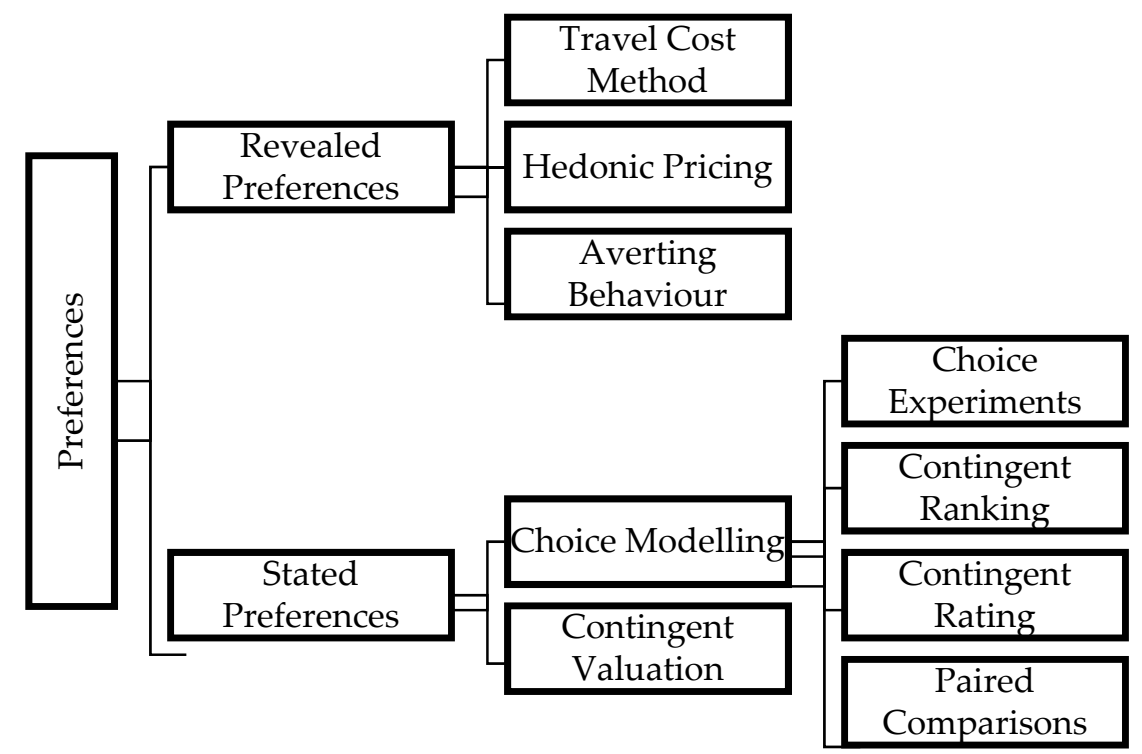

Figure 2. Economic Valuation Methods. Adapted from Garrod and Willis ([79] p. 6), Bateman et al. ([61] p. 30) and Pearce et al. ([59] p. 88). 
From the information in Table 1, we observe that of the studies reviewed, a minority use the revealed preferences methods: seven from the USA, one from Ireland and one from Austria. One of the techniques is the travel cost approach in References [32-35], that can be used to value the hydropower' impacts over recreational rivers' values. The other two studies apply the hedonic pricing technique $[38,40]$, which collects data for example from property markets, where an environmental attribute is implicitly traded. In these two specific studies, the authors infer the use value of environmental goods (aquatic ecosystems, fauna, flora and recreation activities) based on the residential property values.

The other twenty studies presented in Table 1 use the stated preferences methods. Of these, nine studies apply choice experiments, and the remaining studies apply the contingent valuation methodology.

All the studies using the choice experiment technique share the theoretical framework in which respondents are presented with a series of alternatives, differing in terms of attributes and levels, and are asked to choose their most preferred (for guidance on how to apply this technique refer for example to References $[80,81])$. This approach allows the computation of the willingness-to-pay of respondents for the environmental attributes of the good or service, and can thus show the relative importance of some environmental improvements. The results can then be used as the basis for decisions as to projects that affect the environmental assets. The main concerns in these specific choice experiment studies are estimating the values of river water flow, water level, drinking water quality, fauna, flora, forest, historical remains and landscape. These represent not only use values (option, actual, indirect, direct, non-consumptive and consumptive), but also non-use values (existence, for others, altruism and bequest).

The contingent valuation technique was applied in 11 studies on the economic valuation of dams' environmental impacts and consists of a questionnaire that directly elicits consumers' preferences. A hypothetical market is described where the good in question can be traded and respondents are asked to indicate their maximum willingness-to-pay or minimum willingness-to-accept a compensation for a hypothetical change in the level of the environmental good or service (for guidance on how to apply this method refer for example to Johnston et al. [81]). These specific contingent valuation studies propose to mainly assess the values of land use, landscape impacts, impacts on fauna and flora, historical monuments, recreational river sports, and also some social issues. These are use values (option, actual, indirect, direct, non-consumptive and consumptive) and non-use values (existence, for others, altruism and bequest).

Three of the studies in Table $1[5,6,56]$ emphasize key social issues particularly felt among the local communities who often are against the construction of the hydropower facilities in the proximity of their residences.

Social acceptance, or the lack of it, represents one of the most important concerns regarding hydropower development, since the construction and operation of dams is associated to considerable social impacts particularly imposed on the local communities $[28,82,83]$. There is empirical evidence that hydropower projects may worsen the living conditions of local communities and in particular of those who are involuntary displaced and resettled $[28,83,84]$. Hence, considering and evaluation these social impacts caused by dam projects, and eventual displacements and resettlements would be of great importance to hydropower development, as well as devising and implementing measure to mitigate the adverse social impacts [14].

Regarding the application of these two stated preference methodologies, it is important to underline how valuable they are for allowing researchers to infer not only use values, but TEV including both use and non-use values from users and non-users. The latter potentially represent a non-negligible part of the value that individuals and society in general attributes to the environment. In fact, a considerable number of individuals may never expect to make use of some environmental goods and services, but still derive utility from their conservation. Therefore, economic non-use values are increasingly recognized as an important component of TEV and thus a key element when making decisions that can affect the environment, and ultimately society. Moreover, in the case of hydropower where benefits are socially acknowledged and valued, it is important to estimate decreases in non-use 
values related to a dam's construction and operation. Only then can a complete and socially equitable cost-benefit analysis be made.

Worthy of note is the fact that all the studies identified and summarized above reveal non-negligible values for all the impacts under appraisal, providing strong evidence that despite lacking market prices, they do have economic value, and therefore cannot be ignored in proper comparison of benefits and costs for public decisions concerning dams' construction and operations.

\section{Perceptions of Impacts Underlying Non-Use Values by Population Subgroups: A Case Study}

\subsection{Non-Use Values and the Perception of Population Subgroups}

TEV includes components of use and non-use values, which can be elicited by economic valuation methods as illustrated by the selection in the previous section. Throughout this paper, we emphasize non-use values, which have no straightforward market, and yet should be carefully studied so that all costs and benefits of projects are accounted for. As mentioned, the elicitation of non-use values can be done through carefully designed questionnaires, and by creating hypothetical markets where survey respondents state their willingness-to-pay (WTP) for a marginal improvement or willingness-to-accept (WTA) a marginal decrease in a specific environmental good or service, as a consequence of a hydropower plant activity. These values are anthropocentric in that they stem from respondents' utility for a use or non-use component of the good or service and only go as far as respondent's perceptions and preferences allow. This restricts what is captured by the concept of TEV, and neglects, for example, negative impacts that are not known at the time the valuation occurs.

On the other hand, how each respondent perceives the effects of a hydropower project, for example, will affect the valuation of the goods and services affected. Additionally, understanding the value of certain environmental goods or services as use or non-use can depend on certain characteristics of a population subgroup, such as for example being an angler or not, a tourist or not, or a local resident or not. Therefore, we can expect that different subgroups of the population will perceive differently the seriousness of the different dams' impacts based on preferences, past interactions with the RES or being a user or non-user of the particular goods or services. This, in turn, will affect elicited values through stated preference methods.

For the particular case where individuals can be perceived as users or non-users in relation to the hydropower plant impacts, special care should be taken when selecting the sample and designing the questionnaires. Measuring use and non-use values separately is theoretically questionable as it assumes separable utility functions, leading to embedding effects (part-whole or disaggregation bias) $[85,86]$. However, for the case where there are concerns over the equity of RES choices regarding location and size of power plants, it is not necessary to measure use and non-use values separately, but rather that the elicitation of welfare impacts is done for subgroups of the population, in particular between the users and non-users of the area where the dams are installed.

In the case study we present in this paper, we explore perceptions of impacts of hydropower in different population subgroups and test the hypothesis that the perceptions are similar across different objective population characteristics. The alternative hypothesis is for previous experience and contact with the RES or being a user or non-user will condition perceptions. First, we test this hypothesis on data from local residents close to hydropower projects relative to national residents. Second, we can discern in the national sample more or less contact and familiarity with hydropower and split the sample and analyse differences in perceptions, namely across differences in installed capacity in the district of residence, whether individuals see a hydropower plant frequently or whether they have ever visited a dam. In both cases, the "further away" respondents are from hydropower projects, the more likely to perceive essentially non-use values of environmental and social attributes impacted, whereas respondents with more contact are more likely to include use values in their valuation.

We expect stronger views on hydropower from local residents who live in the vicinity of power plants and thus are more directly affected by its adverse impacts. In fact, when stated preference 
(SP) methods are applied, WTP or WTA values are likely to be inflated by the fact that both use and non-use values estimations are made by survey respondents. On the contrary, non-local residents are likely to give more importance to non-use values, with a few eventually including some option value component. It is a fact that the activity of hydropower plants is far from being benign in terms of local environmental and social impacts [1,3], and this is likely to feed into non-use values. Our contribution is to take a step backward and explore perceptions of impacts in a sample contacted for the purpose of economic valuation, to test whether more familiarity and contact with hydropower will impact perceptions of local adverse impacts.

Whitehead [87] shows that quality perceptions significantly influence WTP estimates and should be considered endogenous in the valuation process. Therefore, when applying stated preference methods to valuing economic value of environmental damages of RES, researchers should control for the type of involvement and perception of damages by respondents. Individuals more directly impacted by the RES are likely to perceive the damages more strongly and thus state a higher WTP/WTA. In the case of residents this would be a reflection of the inclusion of user dimensions in their valuations.

\subsection{Case Study: Different Perceptions on Hydropower}

In an encompassing valuation study of the environmental impacts of RES in Portugal, data on the perception of seriousness of environmental and social impacts was collected for the general population and for population living close to RES power plants (please refer to Botelho et al. $[56,88]$ for further details about the questionnaire and valuation section). Some of these studies elicited the WTP by national residents to compensate locals for specific local environmental and social damages of RES through a discrete choice experiment [88]. The other studies elicited the WTA of local residents in terms of compensation through a contingent valuation questionnaire [56]. The values elicited are not directly comparable as in the former case non-use values are likely to be more salient than use-values, given that national residents are being asked to value the adverse impacts on others. In the latter case, the questionnaires were administered to local residents, so both use and non-use values are expected to be significant, or at least more significantly so than in the questionnaire for national residents. The purpose of the studies was not to elicit comparable values, and this is not the aim of the analysis here. However, using these two questionnaires (local residents and national residents), the perception of severity of RES was similarly elicited, which means responses can be directly compared, controlling for the type of involvement with the RES. As such, for the purpose of the present paper, we are able to test whether perceptions towards hydropower differ across measures of proximity and familiarity with the RES.

The questionnaires were administered during 2014. The local questionnaires were conducted as personal interviews carried out by the research team in the vicinity of several dams in operation in Portugal, whereas the national questionnaires were conducted by a professional polling company on a national sample in Continental Portugal. Taking into account the data requirements for the following statistical analysis, there are 15 local residents' questionnaires and 188 national residents' questionnaires.

The null hypothesis under analysis refers to the absence of differences between population subgroups, whereas the alternative hypothesis is that objective population characteristics will generate different perceptions. The following tests will be carried out according to: (a) place of residence (closeness to hydropower plant, i.e., local residents vs. national residents; (b) in terms of installed capacity in the district of residence; (c) whether individuals see a hydropower plant frequently; (d) whether they have visited a hydropower plant. The corresponding alternative hypotheses are:

Hypothesis 1 (H1). Perceptions as to hydropower's local impacts differ between local residents and national residents.

Hypothesis 2 (H2). Perceptions as to hydropower's local impacts depend on installed capacity in the district of residence. 
Hypothesis 3 (H3). Perceptions as to hydropower's local impacts depend on visibility of dam.

Hypothesis 4 (H4). Perceptions as to hydropower's local impacts depend on previous knowledge of dams.

Respondents were asked to rate the effects on specific dimensions of RES from 1 to 5 , where 1 is significant negative impact and 5 is significant positive impact. The dimensions were selected from an extensive literature review, focus group discussions and application of "think-aloud" techniques [89]. Regarding hydropower, the dimensions selected were: effects on landscape, fauna, flora, heritage and noise [88].

We test each of the cases by comparing differences between the distribution of responses (using the Kolmogorov-Smirnov test, KS test) and compare the rank of responses using the Wilcoxon-Mann-Whitney Rank Sum test (WMW test). The full results are in Table 2.

Table 2. Perceptions of local impacts of hydropower by subgroups (Kolmogorov-Smirnov test for equality of distribution and Wilcoxon-Mann-Whitney Rank Sum test).

\begin{tabular}{|c|c|c|c|c|c|}
\hline \multicolumn{6}{|c|}{ (a) Local residents vs. national residents } \\
\hline H1 & Landscape & Fauna & Flora & Heritage & Noise \\
\hline \multicolumn{6}{|c|}{ Combined KS test } \\
\hline$D$ statistic & 0.1348 & 0.1011 & 0.1532 & 0.1911 & 0.1426 \\
\hline$p$-value & 0.931 & 0.996 & 0.85 & 0.619 & 0.9 \\
\hline \multicolumn{6}{|l|}{ WMW test } \\
\hline Z statistic & 1.108 & -0.024 & 0.452 & -0.281 & -0.751 \\
\hline$p$-value & 0.2678 & 0.9811 & 0.6516 & 0.779 & 0.4524 \\
\hline \multicolumn{6}{|c|}{ (b) National residents in lower than median vs. higher than median installed capacity districts } \\
\hline H2 & Landscape & Fauna & Flora & Heritage & Noise \\
\hline \multicolumn{6}{|c|}{ Combined KS test } \\
\hline D statistic & 0.1746 & 0.1944 & 0.1636 & 0.1939 & 0.1583 \\
\hline$p$-value & 0.129 & $0.068^{*}$ & 0.179 & $0.069^{*}$ & 0.208 \\
\hline \multicolumn{6}{|l|}{ WMW test } \\
\hline Z statistic & $-2.179 * *$ & $-2.282^{* *}$ & $-2.11^{* *}$ & $-1.964^{* *}$ & $-2.327^{* *}$ \\
\hline$p$-value & 0.0293 & 0.0225 & 0.0348 & 0.0495 & 0.0199 \\
\hline \multicolumn{6}{|c|}{ (c) National residents who do not see vs. those who see a dam daily } \\
\hline H3 & Landscape & Fauna & Flora & Heritage & Noise \\
\hline \multicolumn{6}{|c|}{ Combined KS test } \\
\hline$D$ statistic & 0.3934 & 0.3878 & 0.3991 & 0.417 & 0.2866 \\
\hline$p$-value & $0.06^{*}$ & $0.066^{*}$ & 0.054 * & $0.038^{* *}$ & 0.3 \\
\hline \multicolumn{6}{|l|}{ WMW test } \\
\hline$Z$ statistic & $2.867 * * *$ & $2.3^{* *}$ & $2.339 * *$ & $2.736^{* * *}$ & $2.264^{* *}$ \\
\hline$p$-value & 0.0041 & 0.0214 & 0.0193 & 0.0062 & 0.0235 \\
\hline \multicolumn{6}{|c|}{ (d) National residents who have not vs. have visited a dam } \\
\hline H4 & Landscape & Fauna & Flora & Heritage & Noise \\
\hline \multicolumn{6}{|c|}{ Combined KS test } \\
\hline D statistic & 0.1891 & 0.1747 & 0.1955 & 0.4171 & 0.2019 \\
\hline$p$-value & 0.261 & 0.348 & 0.209 & $0.038^{* *}$ & 0.198 \\
\hline \multicolumn{6}{|l|}{ WMW test } \\
\hline Z statistic & $-1.824 *$ & -1.499 & -1.562 & $-2.380 * *$ & $-2.089 * *$ \\
\hline$p$-value & 0.0682 & 0.1338 & 0.1182 & 0.0173 & 0.0367 \\
\hline
\end{tabular}

Notes: Responses to the question: "how would you classify each of the following impacts of electricity production through dams, whereby 1 means very negative and 5 means very positive?"; 15 local residents' questionnaires; 188 national residents' questionnaires; levels of statistical significance ${ }^{* *} p<0.01,{ }^{* *} p<0.05,{ }^{*} p<0.10$. 
(a) Local residents vs. national residents (H1)

If local and national residents perceive differently the effects, both subgroups need to be consulted so as to better estimate use and non-use values. In particular, the negative effects on landscape, heritage and noise are expected to feed into higher use values than the effects on fauna and flora, which are likely to have more of an existence or bequest value associated. More proximity to hydropower plants is likely to make residents more sensitive to adverse impacts in the use value components. We thus expect local residents to perceive the negative impacts in those dimensions more strongly than national residents. In terms of the analysis we argue that local residents are akin to users of the environmental and social goods or services impacted by hydropower plants, whereas non-locals are akin to non-users.

However as per Table 2a, in terms of perceptions of impacts, across the five attributes considered, there are no statistically significant differences between the two groups, according to both groups.

(b) Installed capacity in the district of residence (H2)

The national sample can be split in terms of installed capacity of hydropower in the district of residence (above and below the mean) to proxy a higher or lower acquaintance with the energy source. We collect the data from http://e2p.inegi.up.pt/ to calculate the installed capacity of hydropower plants per district. Districts (18) were ranked according to total installed capacity and classified as above median (higher installed capacity) or below median (lower installed capacity). When we split the sample into these two subgroups, we expect that national residents who live in districts with higher intensity of the RES (65 respondents) to have more familiarity with the renewable source and more contact than those in lower intensity districts (123 respondents). More familiarity implies a more accurate perception of local impacts of hydropower.

As observable in Table $2 \mathrm{~b}$, in districts with above median installed capacity, the WMW test yields statistically significant results for all five attributes. Respondents are more positive towards hydropower in those districts than in other districts. More potential contact with hydropower plants improves perceptions.

(c) Hydropower plant visible (H3)

Another question in the national residents' questionnaire concerned familiarity with hydropower through observation of a plant on a daily basis, either from home, work or during commuting. Out of 188 responses, only 11 of responses are positive. In terms of perception, Table 2c shows that those who see on a daily basis a hydropower project perceive the impacts are more negatively than those who do not. The limited sample size does not allow us to draw a clear conclusion. This is, however, a result that warrants future investigation.

(d) Previous contact with hydropower (H4)

To control for more direct contact with a dam, we asked whether respondents had visited one in the past. While the question does not specify the type of visit, it is generic enough to capture if the respondent had seen an actual dam. The majority of respondents had indeed done so (173 out of 188). As for the comparison of perception, the perception of past visitors is more positive than of those who did not come into contact with a dam for landscape impacts, heritage impacts and noise pollution. No statistically significant differences were found in the perception of fauna and flora impacts. In this case, more contact with hydropower improves perceptions.

The results suggest that in fact different subgroups of the population differ in their perceptions. We do not find statistically significant differences between the perception of local and national residents. It would have been appropriate to elicit valuations using the same instrument from both population subgroups, as perceptions are not potentially biasing results.

We do find however differences according to levels of contact with hydropower within the national sample. The above results for $\mathrm{H} 2$ indicate that individuals closer and more likely to be familiar with hydropower perceive its impacts less severely than others. This result is similar to Bakkensen and 
Barrage [90] who find that residents closer to flood prone areas have a significantly lower perception of risk than residents located in objectively lower risk areas. Additionally, individuals who had seen a dam in the past had less damning perception of hydropower than those who had not (H4).

Researchers using stated preference methods are concerned with the so-called hypothetical bias concerning elicited WTP and WTA from hypothetical questions [91]. One potential source is uncertainty about the scenario under valuations and about preferences for the good or service. In fact, Schkade and Payne ([92], p. 88) note that respondents in CV questionnaires seem to "construct their values at the time they are asked". As a consequence, individuals who are more acquainted with, in this case, hydropower will base their responses on prior perceptions, and which can arguably be more accurate, while those not acquainted will form a value based on no prior reflection, which could explain the above results for $\mathrm{H} 2$ and $\mathrm{H} 4$.

\section{Other Considerations}

The focus of this paper is to present an overview of recent studies applying non-market valuation techniques to the impacts caused in particular by the activity of the hydropower plants. Absent from these studies are the impacts of the dams' construction or of the decommissioning stages. As already mentioned, given the age of infrastructure in Europe and the US and the growing importance of hydropower in particular in developing countries [24] we highlight the importance of addressing these stages of hydropower development using these same techniques.

Furthermore, other methods are called for if the researcher is interested in a more encompassing view of the life of a hydropower project, rather than focusing on specific stages. In that case, a more thorough approach would be to develop a Life Cycle Assessment (LCA) of all the impacts caused throughout the dams' lifespan. Briefly, the LCA results so far indicate that the environmental performance of project depends on the specific site and varies depending on the types, scales and locations of projects $[93,94]$. As for the scale, LCA studies show that larger systems normally perform in a more environmentally friendly manner than smaller ones in terms of per kilowatt hour, due to the fact that the former usually have a longer lifespan and greater output $[95,96]$. However, larger projects, present challenges in the decommissioning stage where seldom are large dams demolished [97]. Other LCA studies find that it is the construction phase that contributes mostly to the environmental impact to the whole life cycle of the hydropower plant [98]. Moving beyond LCA, the methodology of Life Cycle Costing (LCC) values the impacts identified in the LCA and makes an economic assessment of the environmental costs throughout the lifecycle of products or investments $[99,100]$.

\section{Discussion}

Environmental economics has a growing and extensive literature on sound procedures to place economic values on non-market environmental goods and services. In this paper, we present a literature overview of some of the main studies published since the year 2000 proposing to assess the use and non-use environmental values impacted by dams' operation. Through the application of different non-market economic valuation methodologies, such as the contingent valuation, choice experiments, the travel cost method and hedonic pricing, the authors of these studies infer a positive monetary amount to different environmental attributes affected by the operation of dams located in different places around the world. This means there is a non-negligible loss to society from the loss of these non-use values. It is also important to note that researchers increasingly use the stated preference methodologies as a result of the recognition of how important are environmental non-use values to an increasingly environmentally conscious society. We also stress the relevance of the psychological and social issues and, although generally not considered (in a total of twenty-eight studies, only three focus on these aspects), these should be treated as key issues in the debate on sustainable hydropower development.

Acknowledging the importance of non-use value in appraising hydropower projects, in this research, we take a step backward and explore perceptions of respondents. We argue that this is an 
important consideration when the valuation of non-use value is to be carried out. For this specific case study, we find that dams' impacts are perceived differently by different groups of the population with more or less contact with hydropower plants, and more or less akin to users and non-users. Researchers and practitioners should thus be aware that the role of user/non-user will affect how individuals perceive the impacts, form their preferences and respond to stated preference questionnaires, and ultimately will have an impact on the elicited values. As this is a case study, the conclusions are not generalizable to other contexts and project-specific analyses necessary.

Therefore, the present paper highlights recent empirical evidence on use and non-use values of impacts associated with hydropower, which implies that failing to incorporate such values in the appraisal of dams' construction and operation is unwarranted and may lead to misguided public decision-making, in the sense that it would be ignoring some of the value lost. It should, however, be noted that while non-market valuation methods can expand the types of costs and benefits included in hydropower projects appraisals, when more complex ecosystems services are considered, other types of analyses are required [101]. Furthermore, the interaction between economics and ecologic and social systems is hard to capture within the cost-benefit analysis framework given the presence of uncertainties and the possibility of irreversibilities in hydropower projects [102]. These issues should not be overlooked, but are, however, beyond the scope of this paper.

In a context where the importance of hydropower is expected to increase in the next decades and old infrastructures are being closed, it is all the more relevant to build upon the existing scarce empirical literature, dust off the economic toolkit and be ready to help policy makers consider non-market values alongside perceptions in their project appraisals and decisions towards hydropower.

Author Contributions: Conceptualization, L.M.C.P., M.V., A.B. and S.S.; investigation, L.M.C.P., M.V., A.B. and S.S.; writing —original draft preparation, S.S.; writing-review and editing, L.M.C.P., M.V., A.B. and S.S.

Funding: L.P. and M.V. acknowledge the funding by Portuguese public funds through FCT—Fundação para a Ciência e a Tecnologia, I.P., in the framework of the project UID/ECO/03182/2019. The funding bodies had no involvement in the conduct of the research or preparation of the article.

Conflicts of Interest: The authors declare no conflict of interest. The funders had no role in the design of the study; in the collection, analyses, or interpretation of data; in the writing of the manuscript, or in the decision to publish the results.

\section{References}

1. Mattmann, M.; Logar, I.; Brouwer, R. Hydropower externalities: A meta-analysis. Energy Econ. 2016, 57, 66-77. [CrossRef]

2. Fogarassy, C.; Kovacs, A. The Cost-Benefit Relations of the Future Environmental Related Developments Strategies in the Hungarian Energy Sector. YBL J. Built Environ. 2016, 4, 33. [CrossRef]

3. IEA/OECD. Benign Energy? The Environmental Implications of Renewables; Organisation for Economic Co-operation and Development and International Energy Agency: Paris, France, 1998.

4. Botelho, A.; Ferreira, P.; Lima, F.; Pinto, L.M.C.; Sousa, S. Assessment of the environmental impacts associated with hydropower. Renew. Sustain. Energy Rev. 2017, 70, 896-904. [CrossRef]

5. Tabi, A.; Wüstenhagen, R. Keep it local and fish-friendly: Social acceptance of hydropower projects in Switzerland. Renew. Sustain. Energy Rev. 2017, 68, 763-773. [CrossRef]

6. Jones, B.A.; Berrens, R.P.; Jenkins-Smith, H.C.; Silva, C.L.; Carlson, D.E.; Ripberger, J.T.; Gupta, K.; Carlson, N. Valuation in the anthropocene: Exploring options for alternative operations of the Glen Canyon Dam. Water Resour. Econ. 2016, 14, 13-30. [CrossRef]

7. McCully, P. Silenced Rivers: The Ecology and Politics of Large Dams (Enlarged and Updated Edition); Zed Books: London, UK, 2001.

8. Klimpt, J.-É.; Rivero, C.; Puranen, H.; Koch, F. Recommendations for sustainable hydroelectric development. Energy Policy 2002, 30, 1305-1312. [CrossRef]

9. Rashad, S.M.; Ismail, M.A. Environmental-impact assessment of hydro-power in Egypt. Appl. Energy 2000, 65, 285-302. [CrossRef] 
10. Bednarek, A.T. Undamming Rivers: A Review of the Ecological Impacts of Dam Removal. Environ. Manag. 2001, 27, 803-814. [CrossRef]

11. Pohl, M.M. Bringing Down Our Dams: Trends in American Dam Removal Rationales. JAWRA J. Am. Water Resour. Assoc. 2007, 38, 1511-1519. [CrossRef]

12. Fencl, J.S.; Mather, M.E.; Costigan, K.H.; Daniels, M.D. How Big of an Effect Do Small Dams Have? Using Geomorphological Footprints to Quantify Spatial Impact of Low-Head Dams and Identify Patterns of Across-Dam Variation. PLoS ONE 2015, 10, e0141210. [CrossRef]

13. Richter, B.D.; Postel, S.; Revenga, C.; Scudder, T.; Lehner, B.; Churchill, A.; Chow, M. Lost in development's shadow: The downstream human consequences of dams. Water Altern. 2010, 3, 14-42.

14. Huang, Y.; Lin, W.; Li, S.; Ning, Y. Social Impacts of Dam-Induced Displacement and Resettlement: A Comparative Case Study in China. Sustainability 2018, 10, 4018. [CrossRef]

15. World Commission on Dams. Social Impact Assessment: WCD Thematic Review V. 2. Environmental and Social Assessment for Large Dams; World Commission on Dams: Cape Town, South Africa, 2000.

16. Égré, D.; Senécal, P. Social impact assessments of large dams throughout the world: Lessons learned over two decades. Impact Assess. Proj. Apprais. 2003, 21, 215-224. [CrossRef]

17. McDonald-Wilmsen, B.; Webber, M. Dams and Displacement: Raising the Standards and Broadening the Research Agenda. Water Altern. 2010, 3, 142-161.

18. Ohno, T. Contextual Factors Affecting the Modes of Interaction in Governance: The Case of Dam Removal in Japan. In Interactive Approaches to Water Governance in Asia; Otsuka, K., Ed.; Springer: Singapore, 2019; pp. 55-76.

19. American Rivers. American Rivers Dam Removal Database. Available online: https://doi.org/10.6084/m9. figshare.5234068.v2 (accessed on 1 July 2019).

20. Young, S.M.; Ishiga, H. Assessment of dam removal from geochemical examination of Kuma River sediment, Kyushu, Japan. Environ. Monit. Assess. 2014, 186, 8267-8289. [CrossRef]

21. Lowry, W.R. Policy Reversal and Changing Politics: State Governments and Dam Removals. State Politics Policy Q. 2005, 5, 394-419. [CrossRef]

22. Pejchar, L.; Warner, K. A river might run through it again: Criteria for consideration of dam removal and interim lessons from California. Environ. Manag. 2001, 28, 561-575.

23. Foley, M.M.; Bellmore, J.R.; O'Connor, J.E.; Duda, J.J.; East, A.E.; Grant, G.E.; Anderson, C.W.; Bountry, J.A.; Collins, M.J.; Connolly, P.J.; et al. Dam removal: Listening in. Water Resour. Res. 2017, 53, 5229-5246. [CrossRef]

24. Moran, E.F.; Lopez, M.C.; Moore, N.; Müller, N.; Hyndman, D.W. Sustainable hydropower in the 21st century. Proc. Natl. Acad. Sci. USA 2018, 115, 11891-11898. [CrossRef]

25. Grabowski, Z.J.; Denton, A.; Rozance, M.A.; Matsler, M.; Kidd, S. Removing dams, constructing science: Coproduction of undammed riverscapes by politics, finance, environment, society and technology. Water Altern. 2017, 3, 769-795.

26. Germaine, M.-A.; Lespez, L. The Failure of the Largest Project to Dismantle Hydroelectric Dams in Europe? (Sélune River, France, 2009-2017). Water Altern. 2017, 10, 655-676.

27. Goodland, R. Viewpoint-The World Bank Versus the World Commission on Dams. Water Altern. 2010, 3, 384-398.

28. World Commission on Dams. Dams and Development: A New Framework for Decision-Making: The Report of the World Commission on Dams; Earthscan: London, UK, 2000.

29. Steiner, A. Preface to the Special Issue WCD+10: Revisiting the large dam controversy. Water Altern. 2010, $3,1-2$.

30. Schulz, C.; Adams, W.M. Debating Dams: The World Commission on Dams 20 Years on; Wiley Interdisciplinary Reviews Water: Hoboken, NJ, USA, 2019; p. e1396.

31. IEA. World Energy Outlook 2018; OECD/IEA: Paris, France, 2018.

32. Loomis, J. Quantifying recreation use values from removing dams and restoring free-flowing rivers: A contingent behavior travel cost demand model for the Lower Snake River. Water Resour. Res. 2002, 38. [CrossRef]

33. McKean, J.R.; Johnson, D.; Taylor, R.G.; Johnson, R.L. Willingness to pay for non angler recreation at the lower Snake River reservoirs. J. Leis. Res. 2005, 37, 178-194. [CrossRef] 
34. Hynes, S.; Hanley, N. Preservation versus development on Irish rivers: Whitewater kayaking and hydro-power in Ireland. Land Use Policy 2006, 23, 170-180. [CrossRef]

35. Robbins, J.L.; Lewis, L.Y. Demolish it and They Will Come: Estimating the Economic Impacts of Restoring a Recreational Fishery1. JAWRA J. Am. Water Resour. Assoc. 2008, 44, 1488-1499. [CrossRef]

36. Getzner, M. Importance of free-flowing rivers for recreation: Case study of the River Mur in Styria, Austria. J. Water Resour. Plan. Manag. 2014, 141, 04014050. [CrossRef]

37. Borisova, T.; Bi, X.; Hodges, A.; Holland, S. Economic Importance and Public Preferences for Water Resource Management of the Ocklawaha River; University of Florida: Gainesville, FL, USA, 2017.

38. Lewis, L.Y.; Bohlen, C.; Wilson, S. Dams, dam removal, and river restoration: A hedonic property value analysis. Contemp. Econ. Pol. 2008, 26, 175-186. [CrossRef]

39. Provencher, B.; Sarakinos, H.; Meyer, T. Does Small Dam Removal Affect Local Property Values? An Empirical Analysis. Contemp. Econ. Policy 2008, 26, 187-197. [CrossRef]

40. Bohlen, C.; Lewis, L.Y. Examining the economic impacts of hydropower dams on property values using GIS. J. Environ. Manag. 2009, 90, S258-S269. [CrossRef]

41. Sundqvist, T. Quantifying Household Preferences over the Environmental Impacts of Hydropower in Sweden: A Choice Experiment Approach. Power Generation Choice in the Presence of Environmental Externalities. Ph.D. Thesis, Luleå University of Technology, Luleå, Sweden, 2002.

42. Bergmann, A.; Hanley, N.; Wright, R. Valuing the attributes of renewable energy investments. Energy Policy 2006, 34, 1004-1014. [CrossRef]

43. Han, S.-Y.; Kwak, S.-J.; Yoo, S.-H. Valuing environmental impacts of large dam construction in Korea: An application of choice experiments. Environ. Impact Assess. Rev. 2008, 28, 256-266. [CrossRef]

44. Kataria, M. Willingness to pay for environmental improvements in hydropower regulated rivers. Energy Econ. 2009, 31, 69-76. [CrossRef]

45. Vega, D.C.; Alpízar, F. Choice experiments in environmental impact assessment: The case of the Toro 3 hydroelectric project and the Recreo Verde tourist center in Costa Rica. Impact Assess. Proj. Apprais. 2011, 29, 252-262.

46. Klinglmair, A.; Bliem, M.G.; Brouwer, R. Exploring the public value of increased hydropower use: A choice experiment study for Austria. J. Environ. Econ. Policy 2015, 4, 315-336. [CrossRef]

47. Xu, L.; Yu, B.; Li, Y. Ecological compensation based on willingness to accept for conservation of drinking water sources. Front. Environ. Sci. Eng. 2015, 9, 58-65. [CrossRef]

48. Botelho, A.; Lourenço-Gomes, L.; Pinto, L.M.C.; Sousa, P.; Sousa, S.; Valente, M. Using Choice Experiments to Assess Environmental Impacts of Dams in Portugal. Aims Energy 2015, 3, 316-325. [CrossRef]

49. Michailidis, A. Impact analysis of irrigation projects: An application of contingent valuation method. Am. J. Agric. Biol. Sci 2006, 1, 17-21.

50. Håkansson, C. Costs and benefits of improving wild salmon passage in a regulated river. J. Environ. Plan. Manag. 2009, 52, 345-363. [CrossRef]

51. Ehrlich, Ü.; Reimann, M. Hydropower versus non-market values of nature: A contingent valuation study of Jägala Waterfalls, Estonia. Int. J. Geol. 2010, 4, 59-63.

52. Alp, E.; Yetiş, Ü. Application of the contingent valuation method in a developing country: A case study of the Yusufeli Dam in northeast Turkey. Water Sci. Technol. 2010, 62, 99-105. [CrossRef]

53. Gunawardena, U.A.D.P. Inequalities and externalities of power sector: A case of Broadlands hydropower project in Sri Lanka. Energy Policy 2010, 38, 726-734. [CrossRef]

54. Ponce, R.D.; Vásquez, F.; Stehr, A.; Debels, P.; Orihuela, C. Estimating the Economic Value of Landscape Losses Due to Flooding by Hydropower Plants in the Chilean Patagonia. Water Resour. Manag. 2011, 25, 2449. [CrossRef]

55. Aravena, C.; Hutchinson, W.G.; Longo, A. Environmental pricing of externalities from different sources of electricity generation in Chile. Energy Econ. 2012, 34, 1214-1225. [CrossRef]

56. Botelho, A.; Pinto, L.M.C.; Lourenço-Gomes, L.; Valente, M.; Sousa, S. Social sustainability of renewable energy sources in electricity production: An application of the contingent valuation method. Sustain. Cities Soc. 2016, 26, 429-437. [CrossRef]

57. Jones, B.A.; Ripberger, J.; Jenkins-Smith, H.; Silva, C. Estimating willingness to pay for greenhouse gas emission reductions provided by hydropower using the contingent valuation method. Energy Policy 2017, 111, 362-370. [CrossRef] 
58. Jones, B.A.; Berrens, R.P.; Jenkins-Smith, H.; Silva, C.; Ripberger, J.; Carlson, D.; Gupta, K.; Wehde, W. In search of an inclusive approach: Measuring non-market values for the effects of complex dam, hydroelectric and river system operations. Energy Econ. 2018, 69, 225-236. [CrossRef]

59. Pearce, D.; Mourato, S.; Atkinson, G. Cost Benefit Analysis and the Environment: Recent Developments; OECD Publishing: Paris, France, 2006.

60. Emerton, L. Economic Valuation of Wetlands: Total Economic Value. In The Wetland Book; Springer: Dordrecht, The Netherlands, 2018; pp. 1-6.

61. Bateman, I.J.; Carson, R.T.; Day, B.; Hanemann, M.; Hanley, N.; Hett, T.; Jones-Lee, M.; Loomes, G.; Mourato, S.; Ozdemiroglu, E. Economic Valuation with Stated Preference Techniques: A Manual; Edward Elgar Publishing: Cheltenham, UK, 2002.

62. Torras, M. The total economic value of Amazonian deforestation, 1978-1993. Ecol. Econ. 2000, 33, $283-297$. [CrossRef]

63. Alcamo, J. Ecosystems and Human Well-Being: A Framework for Assessment; Island Press: Washington, DC, USA, 2003.

64. TEEB. The economics of ecosystems and biodiversity: Ecological and economic foundations. In The Economics of Ecosystems and Biodiversity: Ecological and Economic Foundations; Kumar, P., Ed.; Routledge: Abington, UK, 2012.

65. Weisser, D. A guide to life-cycle greenhouse gas (GHG) emissions from electric supply technologies. Energy 2007, 32, 1543-1559. [CrossRef]

66. Weisbrod, B.A. Collective-consumption services of individual-consumption goods. Q. J. Econ. 1964, 78, 471-477. [CrossRef]

67. Chan, K.M.A.; Goldstein, J.; Satterfield, T.; Hannahs, N.; Kikiloi, K.; Naidoo, R.; Vadeboncoeur, N.; Woodside, U. Cultural Services and Non-Use Values; Oxford University Press: Oxford, UK, 2011.

68. Freeman, A.M., III; Herriges, J.A.; Kling, C.L. The Measurement of Environmental and Resource Values: Theory and Methods; Routledge: Abington, UK, 2014.

69. Kolstad, C.D. Environmental Economics; Oxford University Press: New York, NY, USA; Oxford, UK, 2000.

70. Krutilla, J.V. Conservation reconsidered. Am. Econ. Rev. 1967, 57, 777-786.

71. Boyce, R.R.; Brown, T.C.; McClelland, G.H.; Peterson, G.L.; Schulze, W.D. An experimental examination of intrinsic values as a source of the WTA-WTP disparity. Am. Econ. Rev. 1992, 82, 1366-1373.

72. Plottu, E.; Plottu, B. The concept of Total Economic Value of environment: A reconsideration within a hierarchical rationality. Ecol. Econ. 2007, 61, 52-61. [CrossRef]

73. Madariaga, B.; McConnell, K.E. Exploring existence value. Water Resour. Res. 1987, 23, 936-942. [CrossRef]

74. Bergstrom, J.; Reiling, S. Does existence value exist? In Multiple Objective Decision-Making for Land, Water, and Environmental Management; El-Swaify, S.A., Yakowitz, D.S., Eds.; Lewis Publishers: Boca Raton, FL, USA, 1998; pp. 481-491.

75. Pearce, D. Cost-Benefit Analysis and Environmental Policy. In Environmental Policy: Objectives, Instruments and Implementation; Helm, D., Ed.; Oxford University Press: New York, NY, USA, 2000; pp. 48-74.

76. Crowards, T. Nonuse values and the environment: Economic and ethical motivations. Environ. Values 1997, 143-167. [CrossRef]

77. Champ, P.; Brown, T.; Boyle, K. Primer on Nonmarket Valuation, 2nd ed.; Springer Science+Business Media B.V.: Berlin, Germany, 2017.

78. Dixon, J.A.; Carpenter, R.A.; Fallon, L.A.; Sherman, P.B.; Manipomoke, S. Economic Analysis of the Environmental Impacts of Development Projects; Routledge: Abington, UK, 2013.

79. Garrod, G.; Willis, K. Economic Valuation of the Environment: Methods and Case Studies; Edward Elgar: Northampton, MA, USA, 1999.

80. Hanley, N.; Wright, R.; Adamowicz, V. Using Choice Experiments to Value the Environment. Environ. Resour. Econ. 1998, 11, 413-428. [CrossRef]

81. Johnston, R.J.; Boyle, K.J.; Adamowicz, W.; Bennett, J.; Brouwer, R.; Cameron, T.A.; Hanemann, W.M.; Hanley, N.; Ryan, M.; Scarpa, R.; et al. Contemporary Guidance for Stated Preference Studies. J. Assoc. Environ. Resour. Econ. 2017, 4, 319-405. [CrossRef]

82. Koirala, S.; Hill, D.; Morgan, R. Impacts of the delay in construction of a large scale hydropower project on potential displacees. Impact Assess. Proj. Apprais. 2017, 35, 106-116. [CrossRef] 
83. Verocai, I. WCD Thematic Review V. 2: Contributing Paper: Environmental and Social Impact Assessment for Large Dams-Thematic Review from the Point of View of Developing Countries; eSocialSciences: Navi Mumbai, India, 2009.

84. Egré, D.; Milewski, J.C. The diversity of hydropower projects. Energy Policy 2002, 30, 1225-1230. [CrossRef]

85. Smith, V.K. Nonuse Values in Benefit Cost Analysis. South. Econ. J. 1987, 54, 19-26. [CrossRef]

86. Wattage, P.; Mardle, S. Total Economic Value of Wetland Conservation in Sri Lanka Identifying Use and Non-Use Values. In Wetl. Ecol. Manag.; 2008; Volume 16, pp. 359-369. [CrossRef]

87. Whitehead, J.C. Improving Willingness to Pay Estimates for Quality Improvements through Joint Estimation with Quality Perceptions. South. Econ. J. 2006, 73, 100-111. [CrossRef]

88. Botelho, A.; Lourenço-Gomes, L.; Pinto, L.M.C.; Sousa, S.; Valente, M. Discrete-choice experiments valuing local environmental impacts of renewables: Two approaches to a case study in Portugal. Environ. Dev. Sustain. 2018, 20, 145-162. [CrossRef]

89. Botelho, A.; Lourenço-Gomes, L.; Pinto, L.; Sousa, S. How to design reliable discrete choice surveys: The use of qualitative research methods. In ICOPEV 2014-2nd International Conference on Project Evaluation (Proceedings); University of Minho: Guimarães, Portugal, 2014; pp. 157-166. ISBN 978-989-97050-3-6.

90. Bakkensen, L.A.; Ding, X.; Ma, L. Flood Risk and Salience: New Evidence from the Sunshine State. South. Econ. J. 2019, 85, 1132-1158. [CrossRef]

91. Loomis, J. What's to know about hypothetical bias in stated preference valuation studies? J. Econ. Surv. 2011, 25, 363-370. [CrossRef]

92. Schkade, D.A.; Payne, J.W. How People Respond to Contingent Valuation Questions: A Verbal Protocol Analysis of Willingness to Pay for an Environmental Regulation. J. Environ. Econ. Manag. 1994, 26, 88-109. [CrossRef]

93. Gagnon, L.; Bélanger, C.; Uchiyama, Y. Life-cycle assessment of electricity generation options: The status of research in year 2001. Energy Policy 2002, 30, 1267-1278. [CrossRef]

94. Bhat, I.K.; Prakash, R. LCA of renewable energy for electricity generation systems-A review. Renew. Sustain. Energy Rev. 2009, 13, 1067-1073.

95. Zhang, Q.; Karney, B.; Maclean, H.; Feng, J. Life-Cycle Inventory of Energy Use and Greenhouse Gas Emissions for Two Hydropower Projects in China. J. Infrastruct. Syst. 2007, 13, 271-279. [CrossRef]

96. Ribeiro, F.d.M.; da Silva, G.A. Life-cycle inventory for hydroelectric generation: A Brazilian case study. J. Clean. Prod. 2010, 18, 44-54. [CrossRef]

97. Pacca, S. Impacts from decommissioning of hydroelectric dams: A life cycle perspective. Clim. Chang. 2007, 84, 281-294. [CrossRef]

98. Hanafi, J.; Riman, A. Life Cycle Assessment of a Mini Hydro Power Plant in Indonesia: A Case Study in Karai River. Procedia Cirp 2015, 29, 444-449. [CrossRef]

99. Woodward, D.G. Life cycle costing-Theory, information acquisition and application. Int. J. Proj. Manag. 1997, 15, 335-344. [CrossRef]

100. Klöpffer, W.; Ciroth, A. Is LCC relevant in a sustainability assessment? Int. J. Life Cycle Assess. 2011, 16, 99-101. [CrossRef]

101. de Assis Espécie, M.; de Carvalho, P.N.; Pinheiro, M.F.; Rosenthal, V.M.; da Silva, L.A.; de Carvalhaes Pinheiro, M.R.; Espig, S.A.; Mariani, C.F.; de Almeida, E.M.; dos Santos, F.N. Ecosystem services and renewable power generation: A preliminary literature review. Renew. Energy 2019, 140, 39-51. [CrossRef]

102. Johansson, P.-O.; Kriström, B. The New Economics of Evaluating Water Projects. Annu. Rev. Resour. Econ. 2011, 3, 231-254. [CrossRef]

(C) 2019 by the authors. Licensee MDPI, Basel, Switzerland. This article is an open access article distributed under the terms and conditions of the Creative Commons Attribution (CC BY) license (http://creativecommons.org/licenses/by/4.0/). 